\title{
Damage parameter estimation of the dual ferrite martensite steel on coercive force
}

\author{
V.V.Usov, N.M.Shkatulyak, N.A.Volchok, D.A.Dyachok \\ South Ukrainian National Pedagogical University named after \\ K.Ushinsky, 26 Staroportofrankovskaya Str., 65020 Odesa. Ukraine
}

Received April 10, 2018

\begin{abstract}
The elastic, strength properties, coercive force $H_{c}$ and damage parameter $D$ in different directions of the sheets of dual ferrite-martensite steel in the initial state of the factory delivery as well as after annealing at $250^{\circ} \mathrm{C}$ for one hour are investigated. Significant correlation relationships between mechanical and elastic characteristics with the magnitude of the coercive force were established. The corresponding regression equations with approximation coefficients of at least 0.97 are obtained. Significant correlation bonds (correlation coefficient not less than 0.95 ) were established between the damage parameter $D$, found from the magnitude of the Young modulus change during annealing, and the relative change in the coercive force $\Delta H_{c} / H_{c}$ after annealing. The obtained results open the prospects of using a non-destructive method of measuring the coercive force for estimating the damage accumulation parameter in dual ferrite-martensite steels under study on the basis of correlations between the change in the elastic modulus and the value of the coercive force.
\end{abstract}

Keywords: Young's modulus, coercive force, damage parameter, correlation.

Проведено исследование упругих, прочностных свойств, коэрцитивной силы $H_{c}$ и параметра поврежденности $D$ в различных направлениях листов двухфазной ферритомартенситной стали в исходном состоянии заводской поставки и после отжига при $250^{\circ} \mathrm{C}$ в течение одного часа. Установлены значимые корреляционные связи между механическими, упругими характеристиками, с одной стороны, и величиной коэрцитивной силы, с другой стороны. Получены соответствующие уравнения регрессии с коэффициентами надежности аппроксимации не менее 0,97. Установлены значимые корреляционные связи (коэффициент корреляции не менее 0,95) между параметром поврежденности $D$, найденным по величине изменения модуля Юнга при отжиге, и относительным изменением коэрцитивной силы после отжига $\Delta H_{c} / H_{c}$. Полученные результаты открывают перспективы применения неразрушающего метода измерения коэрцитивной силы для оценки параметра накопления повреждений в двухфазных феррито-мартенситных сталях на основе соответствующих корреляций между изменением модуля упругости и величиной коэрцитивной силы.

Оцінка параметра пошкодження двофазної ферито-мартенситної сталі за коерцитивності сили. В.В.Усов, Н.М.Шкатуляк, Н.А.Дзига, Д.А.Дячок.

Проведено дослідження пружних, міцнісних властивостей, коерцитивної сили $H_{c}$ i параметра пошкодження $D$ у різних напрямках листів двофазної ферито-мартенситної сталі у початковому стані заводської поставки і після відпалу при $250^{\circ} \mathrm{C}$ протягом однієї години. Встановлено значущі кореляційні зв'язки між механічними, пружними характеристиками, з одного боку, і величиною коерцитивної сили, з іншого боку. Отримано відповідні рівняння регресії з коефіцієнтами надійності апроксимації не менше 0,97. Встановлено значущі кореляційні зв'язки (коефіцієнт кореляції не менше $0,95)$ між параметром пошкодження $D$, знайденим за величиною зміни модуля Юнга при відпалі, і відносною зміною коерцитивної сили $\Delta H_{c} / H_{c}$ після відпалу. Отримані 
результати відкривають перспективи застосування неруйнівного методу вимірювання коерцитивної сили для оцінки параметра накопичення пошкоджень у двофазних ферито-мартенситних сталях на основі відповідних кореляцій між зміною модуля пружності і величиною коерцитивної сили.

\section{Introduction}

Dual ferrite-martensite steels belong to alloys with a composite microstructure of ferrite and martensite. Two-phase steels are used, mainly in the automotive industry, due to their good formability and strength [1]. A high value of strength and uniform deformation can reduce the weight of the structure. This makes it advantageous to use such steels also for the production of gas containers [2].

The final properties of steel and products are known to depend on many factors, such as the chemical composition and its distribution over the thickness of the steel, the average grain size and deviousness of their boundaries [3], the crystallographic texture [4], the operating temperature, the duration of the thermal action, etc.

The appearance of a large number of different defects during the operation of equipment from steel indicates the accumulation of damage. The parameter of material damage $D$ is often used in the framework of continuum mechanics to predict the destruction of constructions [5-8]. The original idea of this method belongs to Kachanov [9], who presented the variable of damage $D$ in order to simulate the phenomenon of creep. Since then, many works on this subject have been published, and formal theories have been developed covering destruction and plasticity $[10,11]$. Strictly speaking, the value of $D$ should be determined from the results of electron microscopic studies. However, this method is to some extent selective.

According to Lemaitre, the damage $D$ changes the stress state of the metal due to the action of the effective stress $[12,13]$. In this case, the parameter $D$ can be determined from the defect of the Young's modulus at uniaxial tensile tests by the formula

$$
D_{1}=1-E / E_{0}
$$

where $E$ and $E_{0}$ are the elastic modules of the damaged and undamaged material, respectively.

On the basis of the postulate, known as the energy equivalence [14-18] of undamaged and damaged material, for the uniaxial tension, the parameter $D$ is expressed through the change of the elasticity modulus by relation

$$
D_{2}=1-\left(E / E_{0}\right)^{1} / 2 .
$$

The above described procedure for determining the damage parameter $D$ is destructive, as it requires cutting out the test pieces. It is hardly suitable for estimating the metal damage parameter of a complex geometric shape, for example, after stamping. In this case, it is desirable to use nondestructive methods to assess the degree of accumulation of damages in the volume of a metal, for example, by measuring the coercive force in ferromagnetic metals, in particular steels.

Coercive force $H_{c}$ is one of the main characteristics of ferromagnetic. The coercive force strongly depends on the structure of the material. That is, the coercive force can vary considerably as a result of small changes in metallurgical processing and the chemical composition of the material [19]. This makes it very promising to use the study of coercive force to study the structural state of ferromagnetic construction materials. Moreover, the measurement of coercive force is now an uncomplicated task, thanks to the use of portable coercimeters, which allow measuring the coercive force by imposing an add-on electromagnet on the investigated section of the product without cut the samples [20, 21]. Since there is currently no general theory of magnetic structural analysis, the main method for obtaining information on the structure by measuring of magnetic characteristics is to establish the correlation dependences of the coercive force with the structure, mechanical and elastic properties for each type of steel [22].

The aim of this paper is to establish the correlation of the coercive force between the modulus of elasticity, damage parameter $D$ (found from the magnitude of the elastic modulus change), ultimate strength and yield strength of the dual ferrite-martensite steel.

\section{Experimental}

The material for the study was the samples of the dual ferrite-martensite steel both in the delivery conditions after the factory processing and after annealing in the saw- 


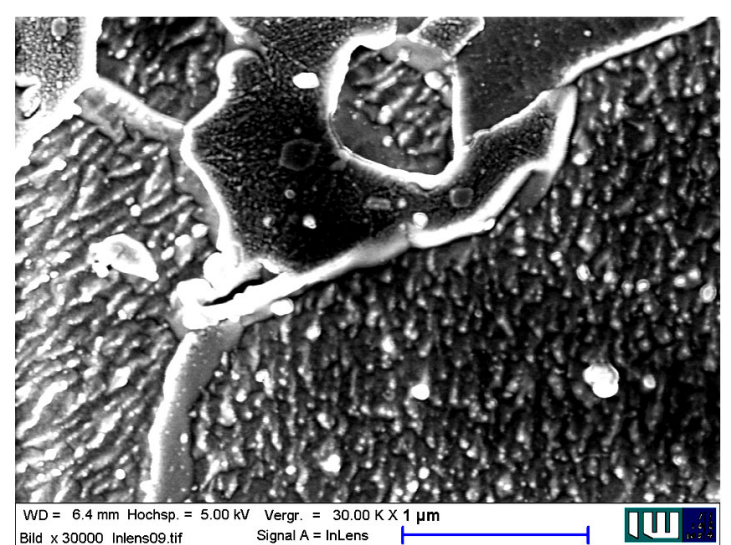

Fig. 1. The microstructure of dual phase ferrite martensite steel in the initial state.

dust at $250^{\circ} \mathrm{C}$ for $1 \mathrm{~h}$. The chemical composition of the steel is shown in Table 1.

The annealing regime was selected in such a way as to obtain the highest values of the modulus of elasticity of the steel being studied, which indicates the lowest level of accumulated damage.

Rectangular samples $100 \mathrm{~mm}$ long and $10 \mathrm{~mm}$ wide were cut from initial and annealed sheets $2 \mathrm{~mm}$ thick through every $15^{\circ}$ from the rolling direction (RD) to the transverse direction (TD) to study the anisotropy of elastic properties. The Young's modulus was measured by dynamic method on the frequency of bending oscillations of a flat sample [23]. The error did not exceed $1 \%$.

At least 3 samples were cut from the initial and annealed sheets in the above directions for mechanical tests for uniaxial tension. The total length of the samples was $100 \mathrm{~mm}$. The length and width of the working part were 30 and $10 \mathrm{~mm}$, respectively. Mechanical tests were carried out on a tearing machine 250N5A WN:143331.

The coercive force was measured by a non-destructive method through every $15^{\circ}$ from the RD to the TD by a magnetic analyzer $\mathrm{MC}-04 \mathrm{H}-2$ (maximum error does not exceed $2 \%$ ) [20].

The setting of the magnetizing current has an operating range of $-2.5 \ldots 2.5 \mathrm{~A}$. The induction is measured in the range of $1.5 \ldots+1.5 \mathrm{~T}$. The measure range of the coercive force is $0.5 \ldots 60.0 \mathrm{~A} / \mathrm{cm}$. The sensor dimensions of the (attachment electromagnet) are $\left.13 \times 12 \times 7.5 \mathrm{~cm}^{3}\right)$. The square pole

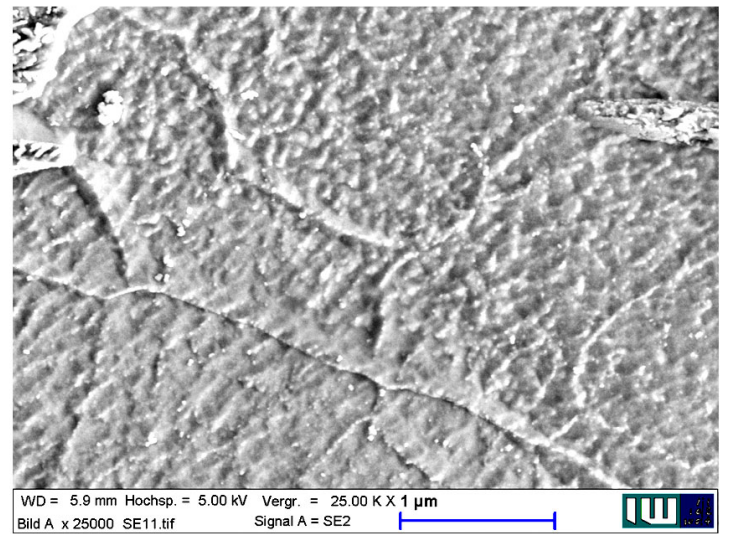

Fig. 2. The microstructure of dual phase ferrite martensite steel after annealing at $250^{\circ} \mathrm{C}$ during the $1 \mathrm{~h}$.

pieces of the sensor had dimensions of $12 \times 12 \mathrm{~mm}^{2}$, the distance between the inner sides of which was $13 \mathrm{~mm}$. In our measurements, the error was not more than $0.1 \mathrm{~A} / \mathrm{cm}$.

An important advantage of the device is that the accuracy depends only on the properties of the metal and does not depend on such interfering factors as a protective coating (paint, film, etc.) with a thickness of up to $6 \mathrm{~mm}$ on the metal being controlled or equivalent corrosion, roughness, curvature of the surface and others [24].

Add-on electromagnet having removable pole pieces and the Hall sensor integrated in the magnetic circuit is a converter in a coercimeter. The principle of operation of the devices is to magnetize the monitored part of the part by imposition an electromagnet to it with subsequent demagnetization by its increasing field, fixing the field strength corresponding to the coercive force of the material, measuring the amplitude of the signal obtained from the Hall sensor.

The microstructure of the steel in the initial delivery state and after annealing was examined using a scanning electron microscope JSM 6700F NT [25]. Before the study, the surfaces were polished, etched in a $4 \%$ solution of picric acid in ethanol, and then subjected to ionic cleaning.

Table 1. Chemical composition of dual ferrite martesite steel, wt. \%

\begin{tabular}{|c|c|c|c|c|c|c|c|c|c|c||}
\hline \hline $\mathrm{C}$ & $\mathrm{Mn}$ & $\mathrm{Cu}$ & $\mathrm{Ni}$ & $\mathrm{Cr}$ & $\mathrm{Al}$ & $\mathrm{Ti}$ & $\mathrm{Si}$ & $\mathrm{P}$ & $\mathrm{S}$ & $\mathrm{Fe}$ \\
\hline 0.081 & 1.45 & 0.056 & 0.071 & 0.212 & 0,029 & 0.002 & $\mathbf{0 . 0 0 5}$ & $\mathbf{0 . 0 2 1}$ & $\mathbf{0 . 0 0 5}$ & Balance \\
\hline
\end{tabular}


V.V.Usov et al. / Damage parameter estimation of ...

Table 2. Mechanical, elastic and magnetic properties of dual ferrite martesite steel

\begin{tabular}{|c|c|c|c|c|c|c|c|c|}
\hline \multirow{2}{*}{$\begin{array}{l}\text { Angle } \\
\text { with } \\
\text { RD, 。 }\end{array}$} & \multicolumn{4}{|c|}{ Initial state } & \multicolumn{4}{|c|}{$\begin{array}{c}\text { State after annealing at } 250^{\circ} \mathrm{C} \\
\text { during the } 1 \mathrm{~h}\end{array}$} \\
\hline & $\sigma_{0.2}, \mathrm{MPa}$ & $\sigma_{U S}, \mathrm{MPa}$ & $E, \mathrm{GPa}$ & $H_{c}, \mathrm{~A} / \mathrm{cm}$ & $\sigma_{0.2}^{250}$ & $\sigma_{U S}^{250}, \mathrm{MPa}$ & $E_{0}^{250}, \mathrm{MPa}$ & $H_{c}^{250}, \mathrm{~A} / \mathrm{cm}$ \\
\hline 0 & 371 & 582 & 207.31 & 8.68 & 444 & 563 & 207.71 & 8.20 \\
\hline 15 & 372 & 583 & 209.02 & 8.80 & 447 & 565 & 209.18 & 8.31 \\
\hline 30 & 373 & 586 & 212.32 & 9.13 & 455 & 571 & 212.63 & 8.57 \\
\hline 45 & 374 & 589 & 215.09 & 9.54 & 463 & 575 & 215.93 & 8.80 \\
\hline 60 & 376 & 591 & 216.27 & 9.89 & 467 & 576 & 217.44 & 8.87 \\
\hline 75 & 378 & 591 & 215.60 & 10.10 & 467 & 574 & 217.36 & 8.82 \\
\hline 90 & 379 & 591 & 213.78 & 10.16 & 467 & 573 & 217.08 & 8.78 \\
\hline
\end{tabular}

\section{Results and discussion}

The microstructure of the studied steel in the initial and annealed state is shown in Fig. 1, 2.

After annealing some structure defects have been healed (Fig. 1). The results of measuring the modulus of elasticity, mechanical characteristics, coercive force and the value of the damage parameter $D$ are presented in Table 2.

Elasticity modulus values of the study steel have increased after annealing (Table 2). This is probably due to the healing of defects [26] of the crystal structure and the reduction of residual stresses that occurred at the factory treatment.

Corresponding values of the coercive force have decreased at the same time in this case. The coercive force is mainly influenced, as is known [27], by the crystallographic texture, grain sizes and residual stresses. The influence of two first factors of the on the magnitude of the coercive force is probably insignificant. The texture and dimensions of the grains after annealing at $250^{\circ} \mathrm{C}$ for $1 \mathrm{~h}$ probably have not changed much, as the recrystallization of the steel under study occurs at higher temperatures [28]. Therefore, the main effect on the magnitude of the coercive force, as well as on the modulus of elasticity, probably could have been the decrease of structural defect number and magnitude of the residual stresses during annealing.

Our correlation analysis was showed that there are significant correlation links between mechanical, elastic characteristics, on the one hand, and the coercive force value, on the other hand. The corresponding regression equations, correlation coefficients $R$ and standard errors $S$ are presented below.

$$
\begin{gathered}
\sigma_{0.2}=4.84 H_{c}+328.9 ; \\
R=0.97 ; S=0.76 \\
\sigma_{B}=6.27 H_{c}+528.18 ; \\
R=0.98 ; \quad S=0.84 \\
E=-7.00 H_{c}^{2}+137.02 H_{c}-454.50 ; \\
R=0.99 ; \quad S=0.68 \\
\sigma_{0.2}^{250}=33.36 H_{c}^{250}+145.34 ; \\
R=0.99 ; \quad S=0.76 \\
\sigma_{B}^{250}=19.03 H_{n}^{250}+407.07 ; \\
R=0.99 ; \quad S=0.76 \\
E_{0}^{250}=15.35 H_{n}^{250}+81.35 ; \\
R=0.99 ; \quad S=0.60 .
\end{gathered}
$$

Correlation relations turned out to be linear, with the exception of the relation (5), where a nonlinear (quadratic) correlation is observed.

The correlation of the damage parameter $D$ found according to (1) and (2) with the coercive force is of special interest. Values of the coercive force were decreased after annealing in comparison with their value in the initial sheet of the study steel (Table 2). It seems reasonable to compare the magnitude of the relative change in the coercive force after annealing $\Delta H_{c} / H_{c}$ with the value of the damage parameter $D$ found from the relations (1) and (2) (Table 3).

As a result of the correlation analysis, nonlinear (quadratic) regression equations were obtained 
Table 3. The parameter of the damage $D$ and the relative change in the coercive force $\Delta H_{c} / H_{c}$ of dual ferrite martesite steel after annealing at $250^{\circ} \mathrm{C}$ during the $1 \mathrm{~h}$

\begin{tabular}{|c|c|c||}
\hline $\begin{array}{c}D_{1}= \\
1-E / E_{0}\end{array}$ & $\begin{array}{c}D_{2}= \\
1-\left(E / E_{0}\right)^{1 / 2}\end{array}$ & $\Delta H_{c} / H_{c}$ \\
\hline 0.0001926 & 0.000963 & 0.0553 \\
0.000765 & 0.000383 & 0.055682 \\
0.001458 & 0.000729 & 0.061336 \\
0.00389 & 0.001947 & 0.077568 \\
0.005381 & 0.002694 & 0.103134 \\
0.008097 & 0.004057 & 0.126733 \\
0.015202 & 0.00763 & 0.135827 \\
\hline
\end{tabular}

$$
\begin{aligned}
& D_{1}=1.60\left(\Delta H_{c} / H_{c}\right)^{2}-0.15\left(\Delta H_{c} / H_{c}\right)+(9) \\
& \quad+4.6 \cdot 10^{-3} ; R=0.96 ; S=1.9 \cdot 10^{-3} \\
& D_{2}=0.97\left(\Delta H_{c} / H_{c}\right)^{2}-0.11\left(\Delta H_{c} / H_{c}\right)+(10) \\
& +4.1 \cdot 10^{-3} ; \quad R=0.95 ; \quad S=9.3 \cdot 10^{-4} .
\end{aligned}
$$

The correlation coefficients have sufficiently high values, and the standard errors are insignificant, as it follows from (9) and (10).

The found nonlinear correlations between the damage parameters (9) and (10) and the relative changes in the coercive force after annealing, as well as between the magnitude of the elastic modulus and the coercive force values in the initial sample (equation (5)) of studied steel can be related to a change in the amount of martensite at annealing by decreasing the solubility of carbon. However, this assumption requires further study.

\section{Conclusion}

The obtained results open the prospects of using a non-destructive method of measuring the coercive force for estimating the damage accumulation parameter in the ferrite-martensite steels under on the basis of correlations between the change in the elastic modulus and the value of coercive force.

\section{References}

1. Dual Phase (DP) Steels. http://www.worldautosteel.org/steel-basics/steel-types/dual- phasedp-steels/

2. Dual Phase Steels. http://www.phasetrans.msm.cam.ac.uk/2008/dual.html

3. V.Usov, E.Gopkalo, N.Shkatulyak et al., Russ. Metallurg. (Metally), 9, 759 (2015).
4. V.Usov, N.Shkatulyak, Mater. Scien., 41, 62 (2005).

5. A.Cipollina, A.LoA pez-Inojosa, J.F1oA rezLoA pez, Comp. Struct., 54, 1113 (1995). .

6. M.Bobyr, O.Khalimon, O.Bondarets, J. Mechan. Eng. NTUU "Kyiv Polytechnic Institute", Visnyk NTUU KPI, Machine Build. Ser., 5 (2013).

7. B.Starman, M.Vrh, M.Halilovic et al., $J$. Mech. Engin., 60, 2 (2014).

8. F.Ghrib, R.Tinawi, J.Eng. Mech., 121, 513 (1995).

9. L.M.Kachanov, Intern. J. Fracture, 97, 11 (1999).

10. E.Rizzi, A.Caro, I.J. Elast., 64, 85 (2001).

11. C.Goidescu, H.Welemane, O.Pantale et al., Intern. J. Damage Mech., 24, 313 (2015).

12. J.Lemaitre, J. Engin. Mater. and Techn., 107, 83(1985).

13. J.Lemaitre, A Course on Damage Mechanics, Berlin and New York: Springer Verlag (1996). 14. C.L.Chow, J.Wang, Intern. J. Fracture, 33, 3 (1987).

15. J.Cordebois, F.Sidoroff, in: J.Boehler, Ed., Mechanical Behavior of Anisotropic Solids, London; Paris: Martinus Nijhoff Publishers; Editions du CNRS, 761 (1979).

16. A.Luo, Y.Mou, R.Han, Intern. J. Fracture, 70, 19 (1995).

17. J.Lemaitre, J.Dufailly, Eng. Fracture Mechan., 28, 643 (1987).

18. C.Tang, A.Plumtree, Eng. Fracture Mechan., 49, 499 (1994).

19. C.Kittel, Rev. Modern Phys., 21, 581 (1949).

20. Magnetic Analyzer MA. http://promsouz.com/pribori14.html

21. Steel. Nondestructive Testing of Mechanical Properties and Microstructure of Steel Products by Magnetic Method. http://meganorm.ru/ Data2/1/4294850/4294850469.pdf

22. B.E.Popov, V.F.Muzhitsky, G.Ya.Bezlyudko et al., http://www.nio12.ru/stati/teoriya-i-praktika-magnitnoj-diagnostiki-stalnyx-metalloko nstrukcij/

23. Elastic Modules: Overview and Characterization Methods. Technical Review ITCME/ATCP. http://www.atcp-ndt.com/images / products/sonelastic/articles/RT03ATCP.pdf

24. V.A.Nekhotyashchii, P.S.Yukhimets, G.Ya.Bezlyudko, Technical Diagnostics and Non-destructive Testing, No. 1, 49 (2010).

25. Electron Microscopy Faculty JSM-6700F SEM

26. L.N.Larikov, Healing of Defects in Metals, Naukova Dumka, Kiev (1980).

27. T.Miyazaki, H.Jin, The Physics of Ferromagnetism, Springer: Berlin Heidelberg (2012).

28. Heat Treatment - Stress Relieving. http://www.engineershandbook.com/MfgMet hods/stressrelieving.htm 